\title{
Immune phenotype of patients with stage IV metastatic inflammatory breast cancer
}

\author{
Sandra V. Fernandez ${ }^{1}$, Alexander W. MacFarlane IV², Mowafaq Jillab², Maria F. Arisi ${ }^{1,3}$, Jennifer Yearley ${ }^{4}$, \\ Lakshmanan Annamalai ${ }^{4}$, Yulan Gong ${ }^{5}$, Kathy Q. Cai ${ }^{6}$, R. Katherine Alpaugh ${ }^{1,7}$, Massimo Cristofanilli, ${ }^{1,8}$ and \\ Kerry S. Campbell ${ }^{2^{*}}$ (i)
}

\begin{abstract}
Background: Inflammatory breast cancer (IBC) is a rare but aggressive carcinoma characterized by severe erythema and edema of the breast, with many patients presenting in advanced metastatic disease. The "inflammatory" nature is not due to classic immune-mediated inflammation, but instead results from tumor-mediated blockage of dermal lymphatic ducts. Previous work has shown that expression of PD-L1 on tumor cells can suppress T cell activation in triple-negative (TN) non-IBC breast cancer. In the present work, we investigated immune parameters in peripheral blood of metastatic IBC patients to determine whether cellular components of the immune system are altered, thereby contributing to pathogenesis of the disease. These immune parameters were also compared to PD-1 and PD-L1 expression in IBC tumor biopsies.
\end{abstract}

Methods: Flow cytometry-based immune phenotyping was performed using fresh peripheral blood from 14 stage IV IBC patients and compared to 11 healthy age-similar control women. Immunohistochemistry for CD20, CD3, PD1, and PD-L1 was performed on tumor biopsies of these metastatic IBC patients.

Results: IBC patients with Stage IV disease had lymphopenia with significant reductions in circulating T, B, and NK cells. Reductions were observed in all subsets of $\mathrm{CD}^{+} \mathrm{T}$ cells, whereas reductions in $\mathrm{CD} 8^{+} \mathrm{T}$ cells were more concentrated in memory subsets. Immature cytokine-producing CD56 bright $N K$ cells expressed higher levels of FcyRllla and cytolytic granule components, suggesting accelerated maturation to cytolytic CD56 ${ }^{\mathrm{dim}}$ cells. Immunohistochemical analysis of tumor biopsies demonstrated moderate to high expression of PD-1 in 18.2\% of patients and of PD-L1 in 36.4\% of patients. Interestingly, a positive correlation was observed between co-expression levels of PD-L1 and PD-1 in tumor biopsies, and higher expression of PD-L1 in tumor biopsies correlated with higher expression of cytolytic granule components in blood CD4 ${ }^{+} \mathrm{T}$ cells and CD56 ${ }^{\mathrm{dim}} \mathrm{NK}$ cells, and higher numbers of $\mathrm{CD}^{+}$effector memory T cells in peripheral blood. PD-1 expression in tumor also correlated with increased infiltration of $\mathrm{CD}_{2} \mathrm{O}^{+} \mathrm{B}$ cells in the tumor.

(Continued on next page)

\footnotetext{
* Correspondence: kerry.campbell@fccc.edu

${ }^{2}$ Blood Cell Development and Function Program, Institute for Cancer

Research, Fox Chase Cancer Center, 333 Cottman Ave, Philadelphia, PA

19111, USA

Full list of author information is available at the end of the article
}

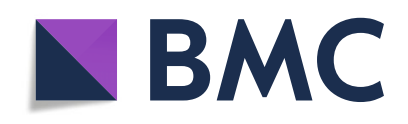

( ) The Author(s). 2020 Open Access This article is licensed under a Creative Commons Attribution 4.0 International License, which permits use, sharing, adaptation, distribution and reproduction in any medium or format, as long as you give appropriate credit to the original author(s) and the source, provide a link to the Creative Commons licence, and indicate if changes were made. The images or other third party material in this article are included in the article's Creative Commons licence, unless indicated otherwise in a credit line to the material. If material is not included in the article's Creative Commons licence and your intended use is not permitted by statutory regulation or exceeds the permitted use, you will need to obtain permission directly from the copyright holder. To view a copy of this licence, visit http://creativecommons.org/licenses/by/4.0/. The Creative Commons Public Domain Dedication waiver (http://creativecommons.org/publicdomain/zero/1.0/) applies to the data made available in this article, unless otherwise stated in a credit line to the data. 
(Continued from previous page)

Conclusions: Our results suggest that while lymphocyte populations are severely compromised in stage IV IBC patients, an immune response toward the tumor had occurred in some patients, providing biological rationale to evaluate PD-1/PD-L1 immunotherapies for IBC.

Keywords: Inflammatory breast cancer (IBC), Stage IV IBC, Metastatic IBC, Lymphopenia, PD-1, PD-L1, Immunotherapy, Checkpoint inhibitors, T cells, NK cells, Tumor-infiltrating lymphocytes, Tumor microenvironment

\section{Background}

Inflammatory breast cancer (IBC) is a rare and aggressive malignancy. In the United States (US), IBC accounts for 2$6 \%$ of all patients with breast cancer $[1,2]$. Although IBC is a relatively rare clinical subtype of locally advanced breast cancer, it is responsible for approximately $10 \%$ of breast cancer-associated deaths annually in the US, which translates into about 4000 deaths per year [3, 4]. Approximately $20-30 \%$ of IBC patients present with distant metastasis (stage IV disease) at diagnosis, compared to $6-10 \%$ of patients with breast cancer that is not inflammatory (nonIBC) [5]. Although recent trends indicate an improvement in survival in IBC patients, the prognosis remains worse than non-IBC cases. The median overall survival (OS) for patients with stage III IBC is 4.75 years, compared to 13.40 years in those with non-IBC, and for stage IV disease OS is 2.27 years in IBC patients versus 3.40 years in non-IBC patients $[6,7]$. IBC patients tend to be younger compared to other breast cancer patients, with a median age at diagnosis of 52 years compared to 57 for non-IBC patients [8].

The principal clinical symptoms of IBC are breast erythema, edema, peau d'orange, and dermal lymphatic invasion [9]. Despite its name, IBC is not associated with a profuse inflammatory response. Rather, the characteristic redness and swelling of the breast are due to obstruction of lymphatic channels in the dermis by tumor cells $[4,10]$.

The current consensus regarding clinical management of IBC includes neoadjuvant systemic therapy (chemotherapy or chemotherapy plus targeted therapy), modified radical mastectomy and level I and II ipsilateral axillary node dissection, post-mastectomy radiotherapy of the chest wall and nodal basin, and adjuvant targeted therapy and hormonal therapy [11]. In the case of stage IV de novo IBC, primary systemic therapy is also recommended, but the decision to use surgery and radiation therapy should be evaluated using a multidisciplinary approach, particularly in those patients who have significant clinical response to systemic therapy [11]. Taxane, doxorubicin, and cyclophosphamide in neoadjuvant systemic therapies have been recommended for stage III primary breast cancer, but there is a clear lack of clinical trials specifically for IBC [11]. For HER2 ${ }^{+}$disease, dual antiHER2 therapy (pertuzumab and trastuzumab) combined with chemotherapy is recommended [11].

Data on risk factors for IBC are limited, and the contributions of hereditary versus environmental or life- style factors remain poorly understood [12]. Although IBC, like non-IBC breast cancers, is a heterogeneous disease and can occur as any of the five molecular subtypes, the disease is most commonly either HER2 overexpressing or triple-negative (TN) [13]. TN breast cancer, which is defined by absence of estrogen and progesterone receptors, and a lack of HER2 overexpression, has a poorer prognosis than other subtypes [14]. Importantly, the TN phenotype breast cancer (non-IBC) has been associated with higher expression of PD-L1 on tumor cells [15]. The interaction of the PD-1 receptor on T cells with its ligand, PD-L1 on tumor- and immune-infiltrating cells, suppresses $\mathrm{T}$ cell-mediated immune responses and may play a role in immune escape by human tumors [16]. The extensive accumulation of tumor emboli in the lymphatic vessels of IBC patients supports the notion that the host immune surveillance system is suboptimal or that the tumor cells have adopted immune escape mechanisms to avoid detection by the host. Several recent studies have provided evidence for immune responses toward IBC, suggesting that patients may benefit from immunotherapies, such as PD-1/PD-L1 blocking antibodies [17-22]. Nonetheless, there is insufficient information on peripheral blood leukocyte immune-phenotypes in IBC patients. In the present work, we utilized flow cytometry and immunohistochemistry analysis to investigate immune parameters of metastatic IBC patients and compared them to healthy female volunteer donors. In addition, we studied the expression of PD-L1 and PD-1 in tumor biopsies of these patients with metastatic IBC. Our study aims to determine whether cellular components of the immune system are altered in IBC patients, thereby contributing to the pathogenesis of the disease.

\section{Methods}

\section{Human subjects and blood sample preparation}

The blood samples used in this study were collected from 14 IBC patients with stage IV disease, who were treated at Fox Chase Cancer Center (FCCC) between 2010 and 2012. Control blood samples were collected and anonymized through the FCCC Biosample Repository from 11 age-similar female healthy volunteers. This study was approved by both the research review committee (RRC) and the institutional review board (IRB) at 
Table 1 Demographics of stage IV IBC patients

\begin{tabular}{|c|c|c|c|c|c|}
\hline $\begin{array}{l}\text { Patient } \\
\text { ID }\end{array}$ & $\begin{array}{l}\text { Age at } \\
\text { diagnosis }\end{array}$ & Race & IBC Subtype at diagnosis & $\begin{array}{l}\text { Months after diagnosis of blood collection and } \\
\text { treatment status }\end{array}$ & Overall Survival (OS) \\
\hline Patient 1 & 42 & $\mathrm{H}$ & $\mathrm{ER}^{-} \mathrm{PR}^{-} \mathrm{Her}^{+}$ & $\begin{array}{l}\text { Month } 18 \\
\text { Treated }\end{array}$ & 67 months \\
\hline Patient 2 & 47 & $C$ & $\begin{array}{l}\text { TN } \\
\text { Secondary IBC }\end{array}$ & $\begin{array}{l}\text { Month } 12 \\
\text { Treated }\end{array}$ & 27 months \\
\hline Patient 3 & 55 & C & TN & $\begin{array}{l}\text { Month } 20 \\
\text { Treated }\end{array}$ & 38 months \\
\hline Patient 5 & 49 & C & $\mathrm{ER}^{-} \mathrm{PR}^{-} \mathrm{Her} 2^{+}$ & $\begin{array}{l}\text { Month } 30 \\
\text { Treated }\end{array}$ & 44 months* \\
\hline Patient 6 & 66 & $C(J)$ & $\begin{array}{l}\mathrm{ER}^{+} \mathrm{PR}^{-} \mathrm{Her} 2^{-} \text {(became TN at } \\
\text { month 8) }\end{array}$ & $\begin{array}{l}\text { Month } 8 \\
\text { Treated }\end{array}$ & $\begin{array}{l}10 \text { months (cardiac } \\
\text { disease) }\end{array}$ \\
\hline Patient 7 & 48 & C & $\mathrm{TN}$ & $\begin{array}{l}\text { Month } 21 \\
\text { Treated }\end{array}$ & 27 months \\
\hline Patient 8 & 32 & C & $\mathrm{ER}^{+} \mathrm{PR}^{-} \mathrm{Her} 2^{-}$ & $\begin{array}{l}\text { Month } 50 \\
\text { Treated }\end{array}$ & 105 months \\
\hline Patient 9 & 55 & A & $\mathrm{ER}^{-} \mathrm{PR}^{-} \mathrm{Her} 2^{+}$ & $\begin{array}{l}\text { Month } 4 \\
\text { Treatment naive }\end{array}$ & 16 months \\
\hline $\begin{array}{l}\text { Patient } \\
10\end{array}$ & 62 & C & $\mathrm{TN}$ & $\begin{array}{l}\text { Month } 32 \\
\text { Treated }\end{array}$ & 37 months \\
\hline $\begin{array}{l}\text { Patient } \\
11\end{array}$ & 61 & C & $\mathrm{TN}$ & $\begin{array}{l}\text { Month } 13 \\
\text { Treated }\end{array}$ & 31 months \\
\hline $\begin{array}{l}\text { Patient } \\
13\end{array}$ & 43 & $C$ & $\mathrm{ER}^{+} \mathrm{PR}^{+} \mathrm{Her} 2^{+}$ & $\begin{array}{l}\text { Month } 1 \\
\text { Treatment naive }\end{array}$ & 87 months \\
\hline $\begin{array}{l}\text { Patient } \\
14^{\dagger}\end{array}$ & 44 & C & $\mathrm{ER}^{-} \mathrm{PR}^{-} \mathrm{Her} 2^{+}$ & $\begin{array}{l}\text { Month } 13 \\
\text { Treated }\end{array}$ & 115 months \\
\hline $\begin{array}{l}\text { Patient } \\
15\end{array}$ & 30 & C & $\mathrm{ER}^{+} \mathrm{PR}^{-} \mathrm{Her} 2^{+}$ & $\begin{array}{l}\text { Month } 22 \\
\text { Treated }\end{array}$ & 39 months \\
\hline $\begin{array}{l}\text { Patient } \\
16\end{array}$ & 69 & A & $\mathrm{ER}^{-} \mathrm{PR}^{-} \mathrm{Her} 2^{+}$ & $\begin{array}{l}\text { Month } 26 \\
\text { Treated }\end{array}$ & 37 months \\
\hline
\end{tabular}

Age at disease onset, race, IBC subtype, time in which blood samples were collected since disease onset, and survival is indicated for each patient. All the patients had metastatic disease at the time of the blood collection and received multiple therapies with the exception of patients 9 and 13

C Caucasian, TN triple-negative, A Asian, $\mathrm{H}$ Hispanic, J Jewish heritage

* Last record available

${ }^{\dagger}$ Patient was breast feeding her baby when she was diagnosed with IBC

FCCC. All patients and healthy controls signed IRBapproved informed consent and HIPAA certification prior to sample collection. Retrospective chart reviews were performed in order to collect patient data, which included age at diagnosis, hormone receptor subtype, and treatment history, as summarized in Table 1. Peripheral blood was collected from IBC patients prior to starting a new line of chemotherapy and was processed within $6 \mathrm{~h}$ of collection. The blood was used to determine total and differential counts of leukocytes and to identify frequencies of lymphocyte subpopulations ( $\mathrm{T}, \mathrm{B}$, and NK cells) according to standardized protocols of immune phenotyping by flow cytometry, as previously described [23, 24]. Whole blood $(20 \mathrm{ml})$ was drawn into heparinized tubes and subsequently mixed in equal proportions with complete RPMI 1640 medium (supplemented with $10 \%$ fetal bovine serum, $100 \mu \mathrm{g} / \mathrm{ml}$ penicillin/streptomycin, $2 \mathrm{mM} \mathrm{L}$-glutamine, $\quad 10 \mathrm{mM}$ HEPES, $1 \mathrm{mM}$ sodium pyruvate, and $50 \mu \mathrm{M} 2$ - mercaptoethanol), layered over Lymphoprep (Axixshield POC AS, Oslo, Norway), and centrifuged at $500 \mathrm{~g}$ for $30 \mathrm{~min}$. The buffy coat was removed and suspended with staining buffer (RPMI1640 without biotin or phenol red, and supplemented with $2.0 \mathrm{~g} / \mathrm{L} \mathrm{NaHCO}_{3}$ and $2.4 \mathrm{~g} / \mathrm{L}$ HEPES, $\mathrm{pH} 7.0$ ).

\section{Antibodies and cell staining for flow cytometry}

The staining panel, monoclonal antibody clones, and sources are shown in Supplementary Table S1. Antibodies in direct surface staining tubes were directly conjugated with fluorophores. Staining for perforin and granzyme B was done after samples were fixed with $2 \%$ paraformaldehyde and permeabilized with PBS containing $0.1 \%$ saponin, $1 \%$ BSA, and $0.1 \%$ sodium azide. Staining for FoxP3 was performed after cells were fixed and permeabilized with the Biolegend FOXP3 Fix/Perm Buffer Set (\#421403). One million cells were stained in each sample on ice for $20 \mathrm{~min}$ in approximately $200 \mu \mathrm{l}$ of staining buffer and 
rinsed twice. Staining tubes that were not fixed/permeabilized were subjected to $100 \mathrm{ng} / \mathrm{ml}$ propidium iodide (Invitrogen) in the second rinsing step to mark dead cells. The BD IMK kit (Catalog \# 340503) was used to determine the percentages and absolute counts in whole blood of the following mature lymphocytes: $\mathrm{T}$ lymphocytes $\left(\mathrm{CD}^{+}\right)$, B lymphocytes $\left(\mathrm{CD} 19^{+}\right)$, helper/inducer $\mathrm{T}$ lymphocytes $\left(\mathrm{CD}^{+} \mathrm{CD}^{+}\right)$, cytotoxic $\mathrm{T}$ lymphocytes $\left(\mathrm{CD}^{+} \mathrm{CD}^{+}\right)$, and natural killer (NK) lymphocytes $\left(\mathrm{CD}^{-}{ }^{-} \mathrm{CD} 16^{+}\right.$and/or $\left.\mathrm{CD}^{-} \mathrm{CD}^{-} 6^{+}\right)$. BD Trucount ${ }^{\text {tix }}$ tubes were used for determining absolute counts.

\section{Flow cytometry instrumentation and data analysis}

Stained cells were analyzed on a Beckman Dickinson (BD) ARIA II flow cytometer with 4 lasers at $633 \mathrm{~nm}$, $488 \mathrm{~nm}, 405 \mathrm{~nm}$, and $365 \mathrm{~nm}$ wavelengths. Absolute lymphocyte counts were analyzed on a BD FACS Calibur flow cytometer. Data were collected with BD FACS Diva software version 6 and analyzed with Flowjo v9.2 (Tree Star Inc., Ashland, OR), Microsoft Excel (v12), GraphPad Prism v5.0d or later (GraphPad Software Inc., La Jolla, CA), and Matlab R2016b (The Mathworks). Single cell events were first gated by a forward scatter height vs. forward scatter area plot and viable cells were then gated by lack of propidium iodide staining. Viable $\mathrm{CD} 45^{+}$cells were split into myeloid and lymphocyte populations by applying a side scatter gate and then divided into subpopulations based on the expression of CD3, CD14, CD16, CD19, CD20, CD27, CD62L, CD45RA, and CD56. Regulatory $\mathrm{T}$ (Treg) cells were quantified as a percent of $\mathrm{CD}_{4}^{+} \mathrm{T}$ cells that were $\mathrm{CD} 25^{\text {high }}$ and $\mathrm{FOXP3}^{+}$. Immune parameters measured are shown in Supplementary Table S2.

\section{Analysis of PD-1 and PD-L1 expression in tumor biopsies}

Surgically obtained tumor samples were placed in $10 \%$ formalin buffer, processed and embedded in paraffin (FFPE), and underwent pathological examination for diagnosis. Whole tissue sections cut from FFPE tissue blocks were deparaffinized and rehydrated with serial passage through changes of xylene and graded ethanol. All slides were subjected to heat-induced epitope retrieval in Envision FLEX Target Retrieval Solution, High $\mathrm{pH}$ (Dako, Carpinteria, CA). Endogenous peroxidase in tissues was blocked by incubation of slides in 3\% hydrogen peroxide solution prior to incubation with primary antibody (anti-PD-L1, clone 22C3, Merck \& Co. Inc., Palo Alto CA, USA, or anti-PD-1 clone NAT105, Cell Marque, Rocklin, CA, for $60 \mathrm{~min}$ ). Antigen-antibody binding was visualized via application of the FLEX+ polymer system (Dako, Carpinteria, CA) for PD-1 and PD-L1, and application of 3, 3' diaminobenzidine (DAB) chromogen (Dako, Carpinteria, CA). Stained slides were counterstained with hematoxylin and cover slipped for review. Stained sections then underwent semiquantitative evaluation of positive cell frequency $(0=$ none, $1=$ rare, $2=$ low, $3=$ moderate, $4=$ high, $5=$ very high), as previously described [25]. Scoring was conducted by a pathologist, with scores incorporating prevalence of both tumor cells and non-tumor cell labeling. PD-1 and PD-L1 expression scores of $>2$ were considered positive in combined tumor and non-tumor cells on the $0-5$ scale.

\section{Measuring tumor-infiltrating lymphocytes (TIL)}

Immunohistochemistry was used to differentiate TIL in the FFPE tumor samples, by staining for CD3 (T cells) and CD20 (B cells). The antibodies and staining procedures used were anti-CD3 prediluted (clone 2GV6; Ventana/Roche, US) and incubated $32 \mathrm{~min}$ at $37^{\circ} \mathrm{C}$; antiCD20 (clone L26; Dako) prediluted (1:1280 in Ventana antibody dilution buffer), incubation $32 \mathrm{~min}$ at $37^{\circ} \mathrm{C}$. The specimens were then counterstained with hematoxylin. For each analysis, evaluation was conducted in the tumor and immediately peri-tumoral areas with quantitation output as the percentage of positive cells relative to total nucleated cells.

\section{Statistical methods}

Flow cytometry data for distinct parameters were quantified either as geometric mean fluorescence intensity (GMFI) or percentage of cells that express a cell surface receptor. Comparisons between immune cell parameters from healthy donors and IBC stage IV patients were performed with a Wilcoxon rank-sum test. $P$ and $R$ values for the significance of correlations between immune parameters were determined using a Spearman test. False discovery rate (FDR) analysis was further performed for comparisons within flow cytometry data using the Benjamini-Hochberg method and significance was defined as an FDR of $<20 \%$ [26].

\section{Results \\ Population studied}

Fourteen female patients with metastatic IBC (stage IV) and 11 healthy female age-similar volunteers were included in the study (characteristics summarized in Table 1). The median age of the IBC patient population at disease onset was 49.5 years old (range 30-69 years old) and the median age at the time of blood drawn was 50.5 years old (range $31-72$ ). The median age of healthy donors was 54 (range 34-70). From the 14 metastatic IBC patients, 2 patients were treatment naïve at the time of blood collection (patients 9 and 13 in Table 1). Of the 12 patients that were treated, 5 patients had $\mathrm{ER}^{-} \mathrm{PR}^{--}$ Her2 $^{-}$(triple-negative, TN) IBC subtype; 4 patients had $\mathrm{ER}^{-} \mathrm{PR}^{-} \mathrm{Her} 2^{+} \mathrm{IBC}$; 1 patient had $\mathrm{ER}^{+} \mathrm{PR}^{-} \mathrm{Her}^{+} \mathrm{IBC}$; and 2 patients had $\mathrm{ER}^{+} \mathrm{PR}^{-} \mathrm{Her} 2^{-} \mathrm{IBC}$ at the time of blood 
collection (Table 1). From patients without treatment at the time of enrollment in the study, 1 patient had $\mathrm{ER}^{-} \mathrm{PR}^{-} \mathrm{Her} 2^{+}$disease and another had $\mathrm{ER}^{+} \mathrm{PR}^{+} \mathrm{Her} 2^{+}$ IBC. The median overall survival for the $5 \mathrm{TN}$ and 9 non-TN patients was 31 months and 44 months, respectively (Table 1).

\section{Lymphocytes in metastatic IBC}

We performed comprehensive immune phenotyping by multi-parameter flow cytometry on fresh peripheral blood samples from each of the IBC patients and healthy controls. Seventy-two immune parameters (Supplementary Table S2) were compared between IBC and healthy donors by Wilcoxon rank-sum test. The absolute counts of $\mathrm{T}$ cells $\left(\mathrm{CD}^{+}\right), \mathrm{B}$ cells $\left(\mathrm{CD} 19^{+} \mathrm{CD}^{-}\right)$, helper $\mathrm{T}$ cells $\left(\mathrm{CD}^{+} \mathrm{CD}^{+}\right)$, cytotoxic $\mathrm{T}$ cells $\left(\mathrm{CD}^{+} \mathrm{CD}^{+}\right)$, and natural killer (NK) cells $\left(\mathrm{CD}^{-} \mathrm{CD}^{-} 6^{+}\right)$in blood were also determined, and median values are shown in Table 2. IBC patients with metastatic disease had a significantly lower absolute lymphocyte count than healthy female donors (median $897 \pm 413$ versus $1976 \pm 855$; Fig. 1a). The absolute number of total NK cells in the peripheral blood of IBC patients was also lower than in healthy donors (117 \pm 80 versus $296 \pm 142$; Fig. 1b), which paralleled reductions in absolute numbers of B cells (137 \pm 101 versus $223 \pm 96$; Fig. 1c) and $\mathrm{T}$ cells $(646 \pm 350$ versus $1496 \pm 763$; Fig. 1d). The five IBC patients with TN disease exhibited some of the most extreme lymphopenia with particularly low levels of $\mathrm{T}$ cells (Fig. 1a, d; TN IBC patients are shown as shaded triangles in Figs. 1, 2 , and 3). It is also worth noting that lymphocyte counts from the two patients that did not receive chemotherapy treatment were similar to other IBC patients (especially comparable to the non-TN treated patients; shown as filled squares in Figs. 1, 2, and 3).

\section{Different subpopulations of T lymphocytes}

The absolute number of $\mathrm{CD}^{+} \mathrm{T}$ helper lymphocytes in the peripheral blood of metastatic IBC patients was significantly lower than in healthy donors (372 \pm 236 versus $873 \pm 701$, respectively; Fig. 1e), with the lowest numbers in the TN patients. Significant reductions were also noted in the absolute numbers of $\mathrm{CD}^{+}$cytotoxic $\mathrm{T}$ lymphocytes $(222 \pm 117$ versus $458 \pm 215$, respectively; Fig. 1f and Table 2). The median CD4/CD8 ratio was also lower at $1.7 \pm 0.7$ for metastatic IBC patients and $2.6 \pm 1.6$ for healthy donors (Fig. 1g and Table 2). In addition, the numbers of $\mathrm{CD} 4^{+} \mathrm{CD} 8^{+} \mathrm{T}$ lymphocytes were lower in the IBC patients $(6 \pm 5$ versus $14 \pm 104$; Fig. $1 \mathrm{~h}$ and Table 2).

$\mathrm{T}$ cell subsets were further delineated by differential staining for CD45RA and CD62L. Lymphopenia was

Table 2 The median number \pm standard deviation of lymphocytes per $\mu$ is indicated for 14 stage IV metastatic IBC patients and 11 healthy donors as assessed using BD Trucount ${ }^{\mathrm{TM}}$ assays

\begin{tabular}{|c|c|c|c|}
\hline & IBC patients & Healthy donors & $p$ values \\
\hline Total lymphocytes per $\mu$ l & $897 \pm 413$ & $1976 \pm 855$ & 0.00018 \\
\hline $\mathrm{CD}^{+} \mathrm{T}$ cells per $\mu \mathrm{l}$ & $646 \pm 350$ & $1496 \pm 762$ & 0.00051 \\
\hline $\mathrm{CD}^{+} \mathrm{T}$ cells per $\mu \mathrm{l}$ & $222 \pm 117$ & $458 \pm 215$ & 0.015 \\
\hline $\mathrm{CD}^{+} \mathrm{T}$ cells per $\mu \mathrm{l}$ & $372 \pm 236$ & $873 \pm 701$ & 0.00093 \\
\hline $\mathrm{CD}^{+}{ }^{+} \mathrm{CD} 8^{+}$cells per $\mu \mathrm{l}$ & $6 \pm 5$ & $14 \pm 104$ & 0.0030 \\
\hline NK cells per $\mu \mathrm{l}$ & $117 \pm 80$ & $296 \pm 142$ & 0.00076 \\
\hline B cells per $\mu l$ & $137 \pm 101$ & $223 \pm 96$ & 0.017 \\
\hline CD4/CD8 ratio & $1.7 \pm 0.7$ & $2.6 \pm 1.6$ & 0.023 \\
\hline $\mathrm{CD}^{+}$central memory cells per $\mu \mathrm{l}$ & $165 \pm 88$ & $335 \pm 296$ & 0.00051 \\
\hline $\mathrm{CD}^{+}$effector cells per $\mu \mathrm{l}$ & $1 \pm 29$ & $12 \pm 13$ & 0.0034 \\
\hline $\mathrm{CD}^{+}$effector memory cells per $\mu \mathrm{l}$ & $68 \pm 39$ & $136 \pm 91$ & 0.0016 \\
\hline $\mathrm{CD}^{+}$naïve cells per $\mu \mathrm{l}$ & $125 \pm 126$ & $382 \pm 330$ & 0.00093 \\
\hline $\mathrm{CD}^{+}$central memory cells per $\mu \mathrm{l}$ & $20 \pm 32$ & $49 \pm 32$ & 0.0048 \\
\hline CD8 ${ }^{+}$effector cells per $\mu \mathrm{l}$ & $43 \pm 39$ & $87 \pm 56$ & 0.37 \\
\hline $\mathrm{CD} 8^{+}$effector memory cells per $\mu \mathrm{l}$ & $46 \pm 54$ & $112 \pm 77$ & 0.035 \\
\hline $\mathrm{CD}^{+}$naïve cells per $\mu \mathrm{l}$ & $89 \pm 68$ & $168 \pm 131$ & 0.052 \\
\hline CD16 GMFI on CD56 bright NK cells & $4896 \pm 3883$ & $3224 \pm 1361$ & 0.023 \\
\hline Granzyme B GMFI on CD56 ${ }^{\text {bright }}$ NK cells & $1257 \pm 1064$ & $578 \pm 474$ & 0.049 \\
\hline Perforin GMFI on CD56 $6^{\text {bright }} \mathrm{NK}$ cells & $9412 \pm 18,059$ & $4564 \pm 4717$ & 0.049 \\
\hline
\end{tabular}

All comparisons with significant $p$ values $<0.05$ also passed false discovery rate testing 


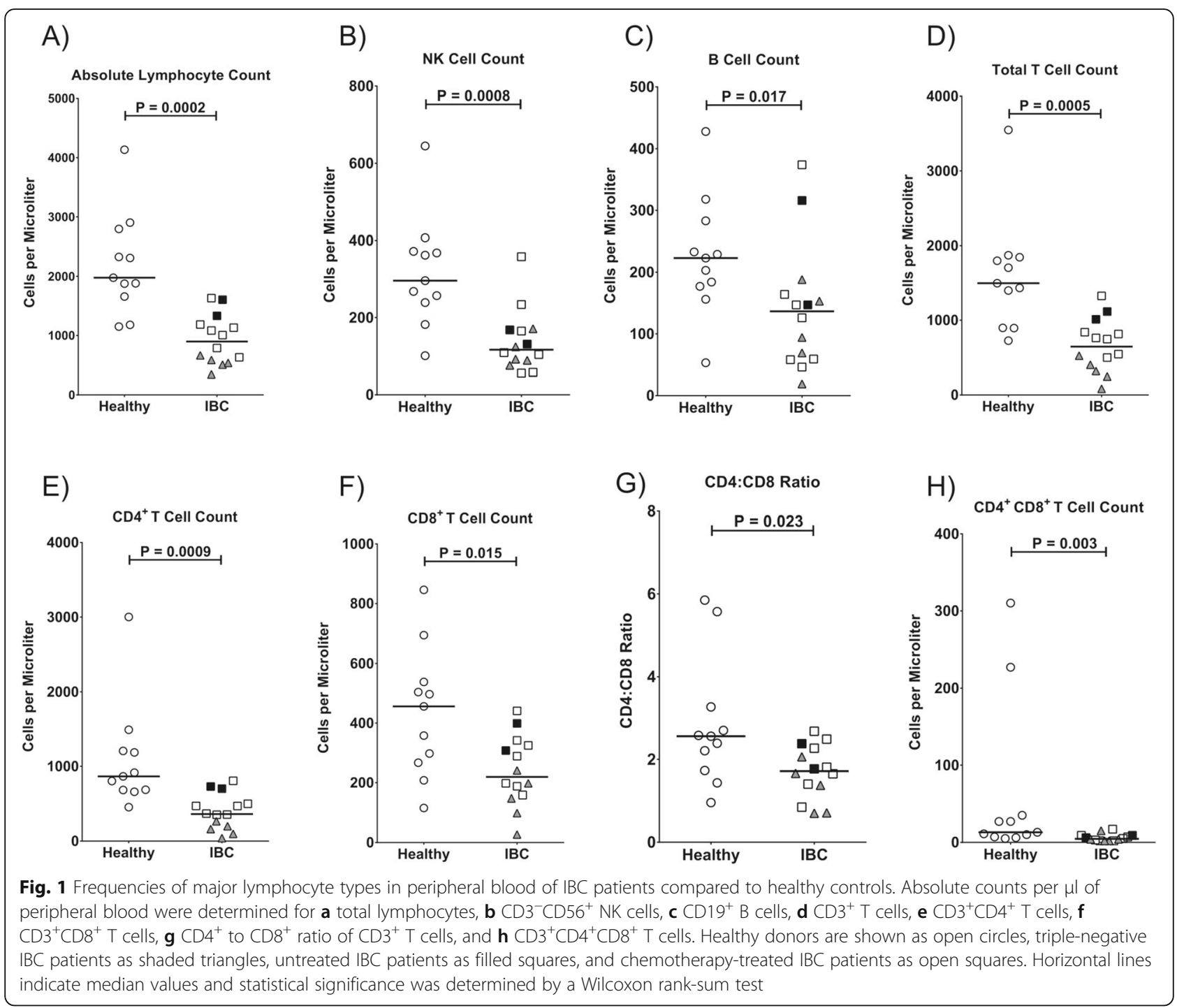

evident in all naive, effector, and memory subsets of $\mathrm{CD}_{4}^{+}$and $\mathrm{CD}^{+}{ }^{+} \mathrm{T}$ cells, but fell short of statistical significance in the naive and effector $\mathrm{CD}^{+} \mathrm{T}$ cell subsets (Fig. 2a-h and Table 2). The more significant reduction of $\mathrm{CD}^{+} \mathrm{T}$ cells in TN patients was particularly evident in $\mathrm{CD}_{4}^{+}$naïve and central memory subsets (Fig. 2a, d).

\section{Natural killer cells}

NK cells provide important innate anti-tumor responses in early and metastatic cancers [27]. Most NK cells in the peripheral circulation are highly cytolytic toward certain tumor target cells and express high levels of perforin and granzyme B in cytolytic granules, low levels of the surface marker CD56 (neural cell adhesion molecule 1; CD56 $6^{\mathrm{dim}}$ ), and high levels of CD16 (FcyRIIIA, lowaffinity receptor for the Fc portion of $\operatorname{IgG}$ ), which can mediate potent antibody-dependent cellular cytotoxicity (ADCC). A less mature, but minor subset of NK cells in human blood expresses high levels of CD56 (CD56 $\left.6^{\text {bright }}\right)$, mediates more cytokine production than cytotoxicity, and generally lacks expression of perforin, granzyme B, and CD16. The amount of CD16 expressed on the surface of immature CD $56^{\text {bright }}$ NK cells in IBC stage IV patients was higher than in healthy donors (median $4896 \pm 3883$ vs. $3224 \pm 1361$ GMFI; Fig. 3a and Table 2), although the expression was not different in the $\mathrm{CD}_{56} 6^{\text {dim }}$ NK cells (data not shown). CD56 $6^{\text {bright }}$ NK cells in metastatic IBC patients also tended to have higher expression of granzyme B $(1257 \pm 1064$ vs. $578 \pm 474$ GMFI; Fig. $3 \mathrm{~b}$ and Table 2) and perforin $(9412 \pm 18,059$ vs. $4564 \pm 4717$ GMFI; Fig. $3 c$ and Table 2) than in healthy donors. All of these changes suggest that the CD56 ${ }^{\text {bright }}$ NK cells may be expressing markers characteristic of more mature CD $56^{\mathrm{dim}}$ cells because they are rapidly maturing to replenish the depleted pool of NK cells. 


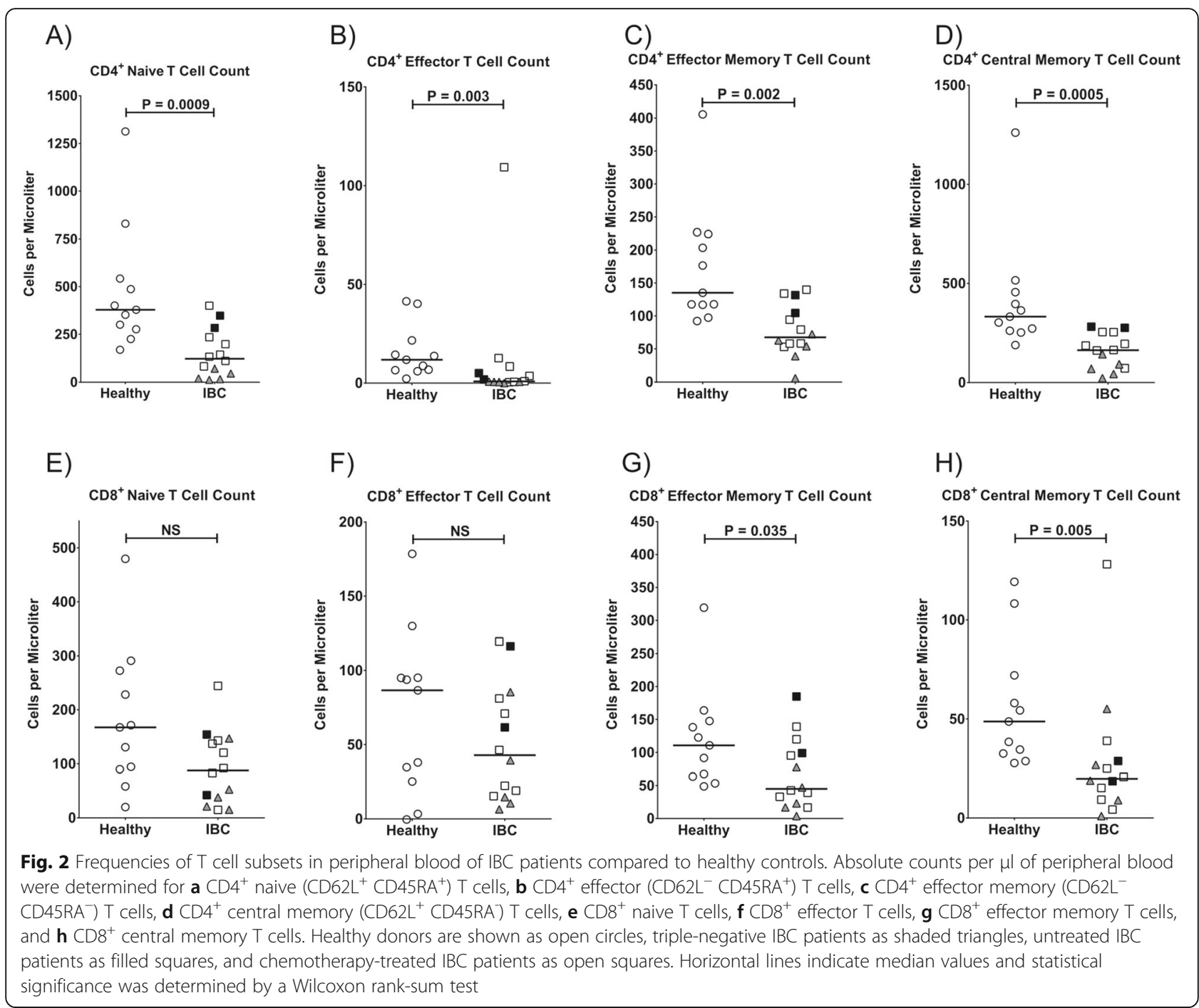

\section{PD-1 and PD-L1 expression in IBC tumors}

We were able to evaluate PD-1 and PD-L1 expression levels by immunohistochemistry (IHC) analysis in tumor biopsies from 11 of the 14 stage IV IBC patients. Biopsy details are provided in Supplementary Table S3, and representative IHC staining is shown in Fig. 4a. PD-1 expression with this assay was observed only on TIL, and while PD-L1 expression may be observed on a variety of cell types, it was observed exclusively on infiltrating immune cells in this particular cohort of samples. A $0-5$ point system was used to score expression patterns with " 5 " being the highest level, as described in the "Methods" section. Since more than one tumor sample was evaluated for some patients, we report the highest score from repeat samples as the value for a particular patient in Fig. 4b, but values for all samples are reported in Supplementary Table S3. As shown in Fig. 4c, the highest level of PD-1 expression was scored as " 3 " (moderate) in only two patients (18.2\%). PD-L1 expression levels were more diverse with expression scored as " 4 " (high) in four patients (36.4\%) (Fig. 4b). Interestingly, a positive correlation was observed between co-expression of PD-1 and PD-L1 in the tumor samples from the IBC patients (Fig. 4c).

\section{Correlations of parameters in blood to PD-L1 in tumor samples}

We next explored whether expression levels of PD-L1 in tumor biopsies correlated with immune biomarkers on $\mathrm{T}$ and NK cells in peripheral blood. Eight of the biopsy samples were obtained within 1 month of the blood analyzed by flow cytometry (Fig. 4b and Supplementary Figure S3), and these were used for correlation analysis between tumor and blood samples. A significant positive correlation was observed between PD-L1 in the tumor biopsies and granzyme $\mathrm{B}$ expression level in CD56 ${ }^{\mathrm{dim}}$ NK cells in peripheral blood, as shown in Fig. 5a. A positive correlation was also noted for PD-L1 expression in 


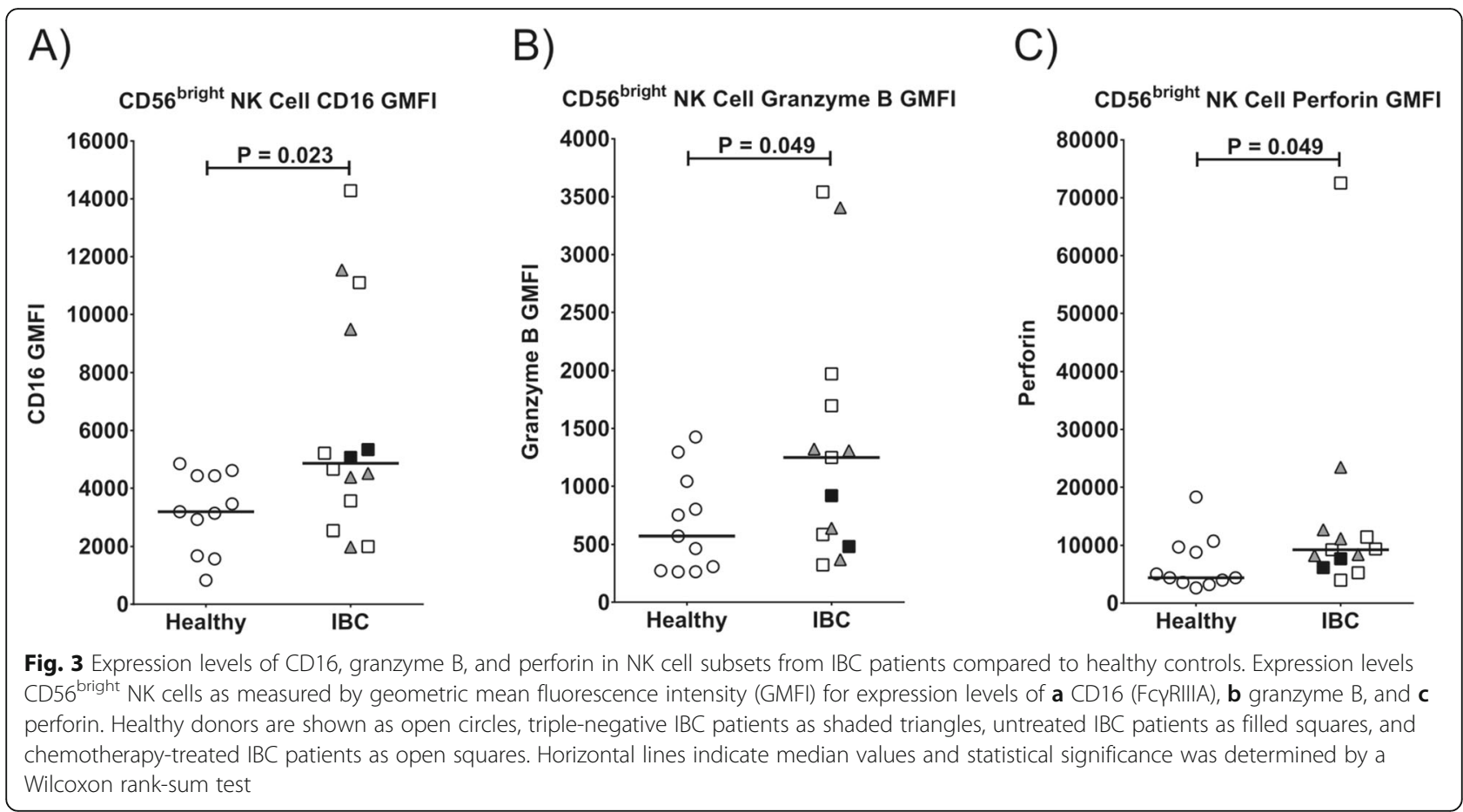

tumor biopsies and both granzyme B and perforin in $\mathrm{CD}^{+}$helper $\mathrm{T}$ cells in peripheral blood, which characteristically express very low levels of these cytolytic granule-associated proteins (Fig. 5b, c). As shown in Fig. 5d, a higher PD-L1 IHC score in tumor samples was also found to correlate significantly with higher numbers of $\mathrm{CD}^{+}$effector memory cytotoxic $\mathrm{T}$ cells in peripheral blood. A higher PD-L1 score in tumor biopsies was also significantly correlated with a reduced percentage of naïve $\mathrm{CD}^{+} \mathrm{T}$ cells in the blood (Fig. 5e). Therefore, our data demonstrate that higher expression of PD-L1 in the stage IV IBC tumor microenvironment (TME) increases cytolytic granule components in blood $\mathrm{NK}$ and $\mathrm{CD} 4^{+} \mathrm{T}$ cells and appears to shift the $\mathrm{CD}^{+} \mathrm{T}$ cell pool from naïve toward an effector memory phenotype in peripheral blood, suggesting that an immune response had occurred in many of these patients, presumably toward the IBC tumor.

\section{Correlations of TIL and PD-1 and PD-L1 in tumor samples}

Given the correlations of PD-L1 expression in the tumors and immune parameters in the blood, we also assessed whether PD-1 and PD-L1 in these tumors correlated with tumor-infiltrating lymphocytes (TIL). The tumors were stained by IHC for CD3 to quantify infiltrating $\mathrm{T}$ cells and CD20 to quantify B cells, and examples of staining are shown in Fig. 6a. The infiltrating $T$ and $B$ cells were quantified as percentage of positive cells relative to the nucleated cells within each tumor and immediate peri-tumoral space. The percentage of infiltrating $\mathrm{T}$ and $\mathrm{B}$ cells did not correlate with any of the immune parameters in the blood. On the other hand, the B cell infiltration correlated significantly with expression of both PD-1 and PD-L1 in tumor, as shown in Fig. 6b, c, although only the correlation with PD-1 passed FDR analysis. A trend was also noted for a correlation between $\mathrm{T}$ cell infiltration and expression of PD-1, which was statistically significant by Wilcoxon analysis, but did not pass FDR analysis, as shown in Fig. 6d.

\section{Discussion}

In the present work, we studied the immune profile of 14 IBC patients with stage IV disease and compared to 11 age-similar healthy controls. The analysis of fresh peripheral blood showed that the most notable parameter that differed in the immune cells of the patients with metastatic IBC was lymphopenia. Our data showed significant deficits in numbers of $\mathrm{T}, \mathrm{NK}$, and $\mathrm{B}$ lymphocytes in peripheral blood of stage IV IBC patients. Although we cannot rule out that some of the lymphopenia in our patient population may have resulted from prior chemotherapy, we show that lymphocyte subset counts from our two treatment naïve IBC patients were generally consistent with treated non-TN IBC patients and nearly always below the medians of our healthy controls, indicating a disease-related impact. A previous study by Reuben and Lee also demonstrated that patients with metastatic IBC had lymphopenia associated with significantly lower $\mathrm{CD} 4^{+} \mathrm{T}$ and $\mathrm{B}$ cells, but higher counts of monocytes in peripheral blood as 
A)

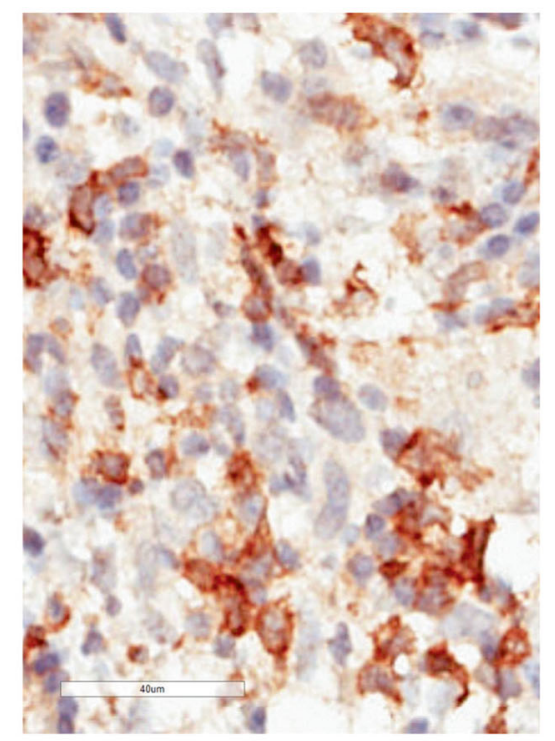

B)

Maximum Measured PD-1 and PD-L1

\begin{tabular}{|c|c|c|}
\hline Patient \# & PD-1 & PD-L1 \\
\hline 2 & 0 & 0 \\
\hline 3 & 1 & 0 \\
\hline 6 & 1 & 2 \\
\hline 7 & 0 & 0 \\
\hline 9 & 3 & 4 \\
\hline 10 & 1 & 2 \\
\hline 11 & 3 & 4 \\
\hline 13 & 2 & 2 \\
\hline 14 & 0 & 4 \\
\hline 15 & 0 & 1 \\
\hline 16 & 2 & 4 \\
\hline
\end{tabular}

PD-L1

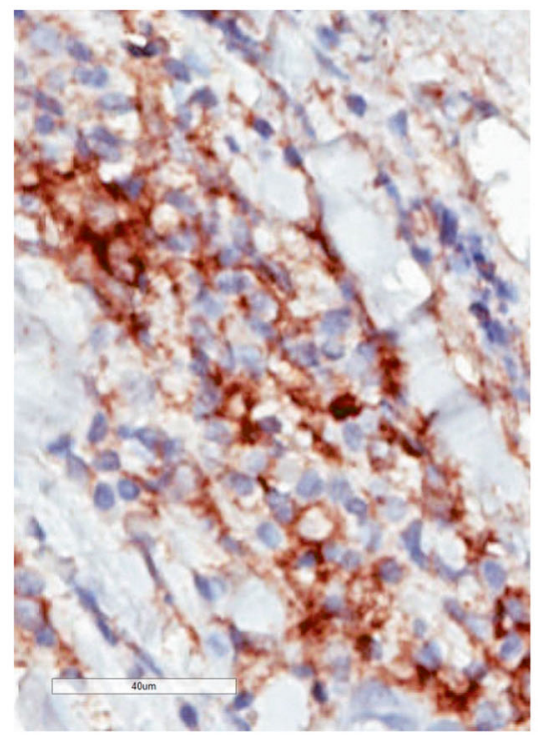

C) PD-1 vs. PD-L1

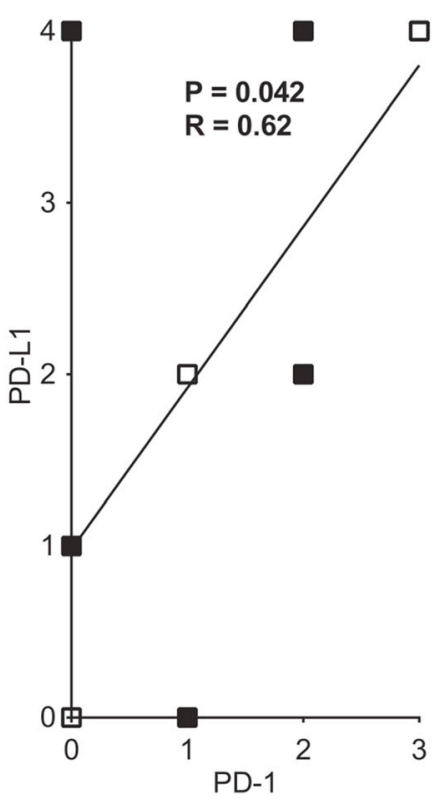

Fig. 4 Analysis of PD-1 and PD-L1 expression in tumor biopsies from stage IV IBC patients. Sixteen tumor biopsy samples from 11 patients were stained by immunohistochemistry for PD-1 and PD-L1. Biopsies from patients \#1, 5, and 8 were not available for evaluation. Details on biopsies are provided in Supplementary Table S3. a PD-1 and PD-L1 staining in brown is shown in samples from a representative patient. Magnification is $\times 600$ in each image and bars designate $40 \mu \mathrm{m}$. b The expression scores for PD-1 and PD-L1 for tumor biopsy samples from the 11 patients assayed. Score definitions are provided in the "Methods" section. Values represent the maximum measured PD-1 or PD-L1 values in cases where a second measurement was made (all values shown in Supplementary Figure S3). Gray shaded patients had blood samples acquired within 1 month of tumor biopsies and were utilized for blood to tumor comparisons in Fig. 5. c Positive correlation between PD-L1 score ( $y$-axis) and PD-1 score ( $x$-axis) from the 11 patients evaluated using maximum values from panel $\mathbf{b}$. Open squares designate overlapping datapoints from two patients. $P$ and $R$ values were computed from a Spearman test. The line is a least-squares fit to the data that is provided for visual purposes 


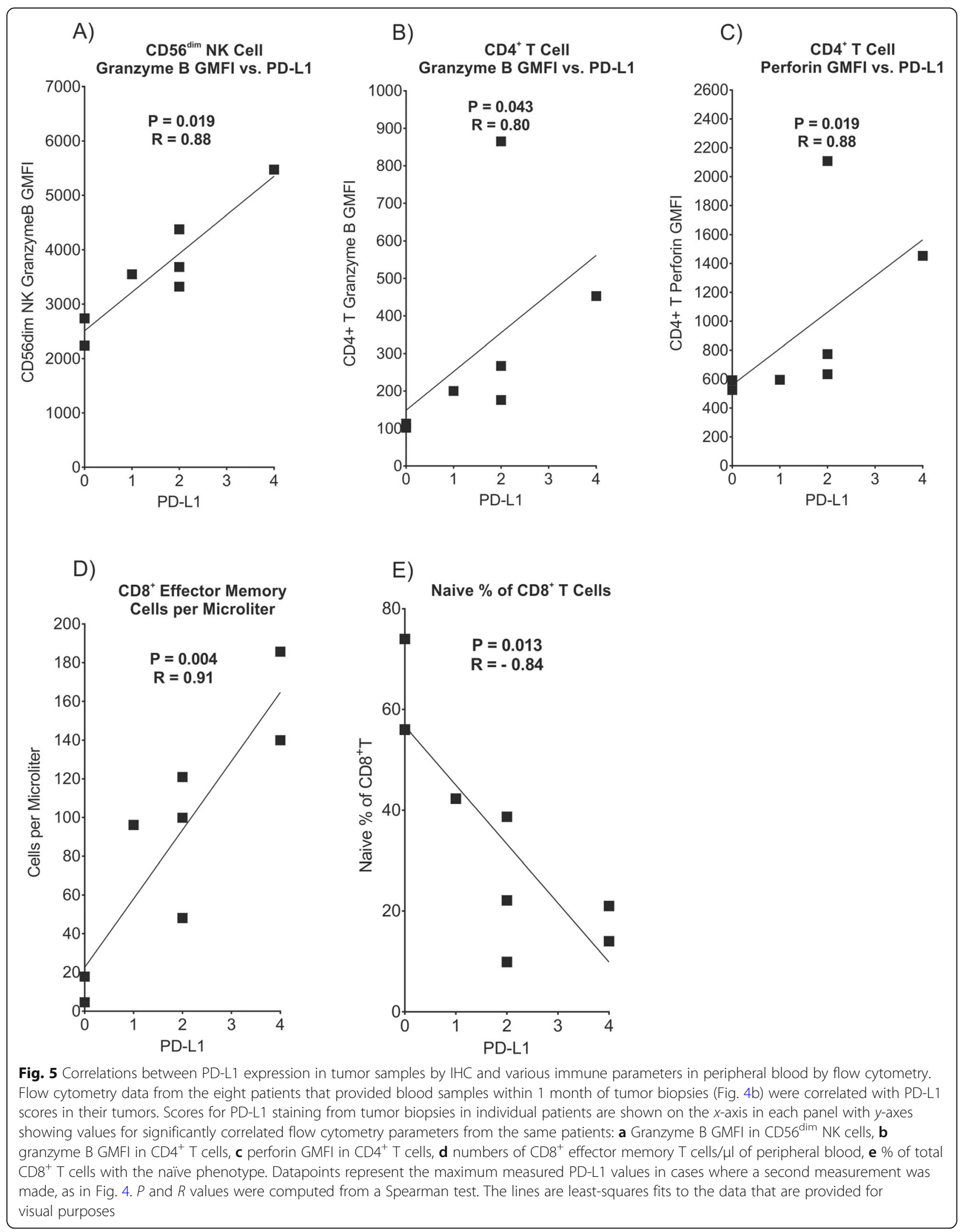




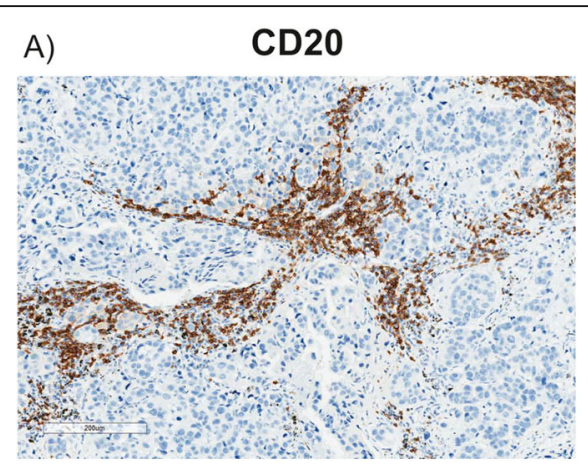

B) $\quad$ CD20+ TIL vs. PD-1

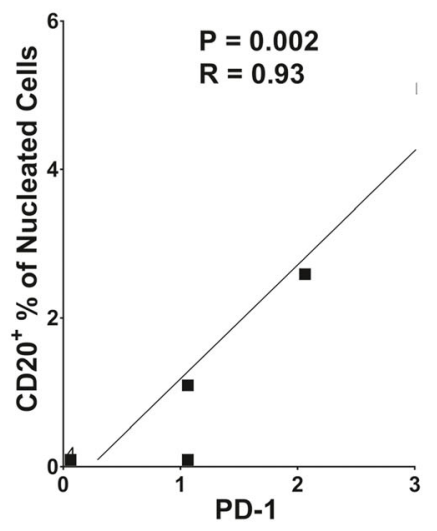

D) $\quad$ CD3 ${ }^{+}$TIL vs.

PD-1

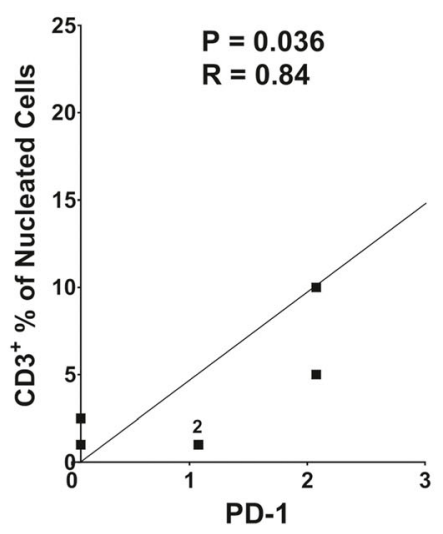

\section{CD3}

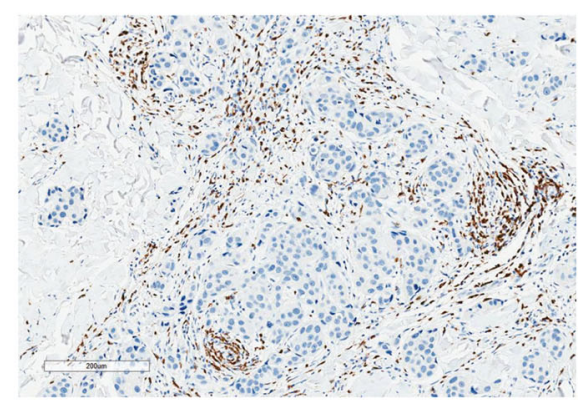

C) $\mathrm{CD}^{2} 0^{+}$TIL vs. PD-L1

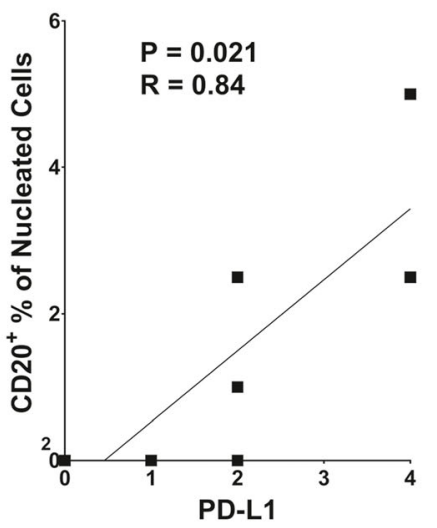

Fig. 6 Correlations between PD-1 and PD-L1 expression in tumor samples and infiltrating T and B cells by IHC. The eight tumor samples analyzed in Fig. 5 were stained for CD3 to mark infiltrating T cells, CD20 to mark infiltrating B cells, and hematoxylin. The sample from patient 10 had limited available tissue, so this was excluded from the CD3 staining analysis. a CD3 and CD20 staining in brown is shown in samples from a representative patient. Magnification is $\times 100$ in each image and bars designate $200 \mu \mathrm{m}$. Percentages of $\mathrm{CD}^{+}$or $\mathrm{CD}_{2} \mathrm{O}^{+} \mathrm{TIL}$ were assessed by a pathologist as percentage of positive cells relative to total nucleated cells in tumor and immediately peri-tumoral areas. Percentage scores for staining of TIL (x-axis) were correlated to scores for PD-1 and PD-L1 (y-axis) from the same tumor biopsies in individual patients are shown as: $\mathbf{b}$ $\% \mathrm{CD}_{2} 0^{+}$TIL vs. PD-1, c \% CD20+ TIL vs. PD-L1, and $\mathbf{d} \% \mathrm{CD}^{+}$TIL vs. PD-1. Numbers next to square icons designate the number of multiple superimposed data points at that position

compared to healthy controls, whereas these cell counts were similar to healthy controls in IBC patients with non-metastatic disease [28]. Mego et al. also reported more severe decreases in absolute lymphocyte count of IBC patients with metastatic disease [29]. 
Our results expand upon previous studies by showing that the numbers of all subpopulations of $\mathrm{CD} 4^{+}$helper $\mathrm{T}$ cells (naïve, central memory, effector memory, and effector) were significantly lower in stage IV IBC patients, whereas reductions within $\mathrm{CD} 8^{+}$cytotoxic $\mathrm{T}$ lymphocytes were more concentrated in the memory subsets. $\mathrm{CD}^{+} \mathrm{T}$ lymphocytes enhance tumor antigen-specific immune responses by producing cytokines, and $\mathrm{CD} 8^{+} \mathrm{T}$ cells provide key adaptive anti-tumor immunity through their production of IFN- $\gamma$ and cytolytic activity [30]. While naïve $\mathrm{T}$ cells have not yet been activated and exist in a resting state, effector $\mathrm{T}$ cells are short-lived and exhibit low proliferative capacity, but elicit potent functional responses toward an antigenic target [31]. The memory subsets provide more rapid and robust secondary responses upon re-exposure to antigens, whereupon they differentiate to an effector state. Central memory $\mathrm{T}$ cells have the most potent proliferative capability and longevity, but weakest functional responsiveness, while effector memory cells have intermediate properties between central memory and effector T cells [31].

It should be noted that lymphopenia is more common in patients with a variety of advanced tumors, as compared to those with localized disease [32]. In particular, reductions in peripheral $\mathrm{CD} 4^{+} \mathrm{T}$ lymphocytes are commonly observed in advanced cases of pancreatic cancer, melanoma, non-Hodgkin lymphoma, sarcoma, hepatocellular carcinoma, and breast cancer [32]. Lymphopenia, particularly the low frequency of $\mathrm{CD} 4^{+} \mathrm{T}$ cells, in patients with advanced cancer has also been shown to correlate with performance status, unfavorable prognostic factors, and worse survival [32, 33].

Our data support the findings of Reuben and Lee, which reported that the $\mathrm{CD} 4 / \mathrm{CD} 8$ ratio of nonmetastatic IBC patients was significantly higher than in metastatic IBC patients, because the non-metastatic IBC patients had a significantly greater reduction in $\mathrm{CD} 4^{+}$ helper T lymphocytes than healthy controls [28]. In contrast, Mego et al. did not observe any alterations in CD4/CD8 $\mathrm{T}$ cell ratio between patients with metastatic or non-metastatic IBC and healthy normal donors [29]. Of note, the percentage of $\mathrm{CD}_{4}^{+} \mathrm{T}$ cells that were $\mathrm{FoxP}^{+}$and $\mathrm{CD} 25^{\text {high }}$ (regulatory $\mathrm{T}$ cells; Treg) did not differ between our IBC patient and healthy control cohorts (data not shown), in contrast to the Mego et al. report of decreased numbers of Tregs in metastatic IBC patients compared to non-metastatic IBC patients and healthy controls [28].

While our study showed reduced numbers of peripheral NK cells in metastatic IBC, Reuben and Lee found no significant reductions in NK cells of metastatic or non-metastatic IBC patients, as compared to healthy controls [28]. NK cells constitute approximately $5 \%$ of the lymphocytes in healthy human peripheral blood and are involved in controlling tumor progression and metastases in a variety of contexts [34]. Two major NK cell subsets are found in human subjects that can be distinguished by their levels of CD56 expression, namely CD56 ${ }^{\text {dim }}$ and CD56 $6^{\text {bright }}[35]$. CD56 $6^{\text {bright }}$ NK cells make up approximately $2-10 \%$ of total NK cells in peripheral blood, are less mature, more apt to leave the vasculature, more efficient at producing cytokines, and less cytolytic than $\mathrm{CD} 56^{\mathrm{dim}}$ cells. The predominant cytolytic targets of NK cells are rare cells that have downregulated expression of class I MHC (MHC-I), which is normally expressed on healthy nucleated cells of the body [36]. MHC-I loss is a common mechanism by which tumors and virus-infected cells can evade recognition by cytolytic T cells, and NK cells can thereby overcome this potential immunologic evasion mechanism [27]. A counterbalance of signals from activating and MHC-Ibinding inhibitory receptors on NK cells regulate their responsiveness [37]. Non-IBC tumors commonly express ligands for the NK cell activating receptors, DNAM-1 and NKG2D, which can increase their susceptibility to attack [38]. CD56 ${ }^{\mathrm{dim}}$ NK cells express the activating receptor CD16 (low-affinity FcyRIIIA) and mediate cytotoxicity by the directed exocytosis of perforins and granzymes from cytolytic granules, which perforate the target cell plasma cell membrane and trigger apoptosis, respectively [39]. A previous report described increased frequencies of immature and non-cytolytic NK cells in advanced non-IBC patients [40], although such a shift was not evident in our study. Instead, our data showed that IBC patients had higher expression levels of CD16, granzyme $\mathrm{B}$, and perforin on their CD56 $6^{\text {bright }} \mathrm{NK}$ cells, suggesting that these immature cells are undergoing accelerated maturation to replenish the diminished mature CD56 ${ }^{\text {dim }}$ population. In contrast to our observed increase in CD16 expression in stage IV IBC, a previous report showed decreased expression of activating NK cell receptors, including CD16, during progression of non-IBC, while inhibitory receptors increased and this correlated with decreased NK cell function, at least partially due to TGF- $\beta 1$ in the TME [41].

Our study also provides further evidence that the immune system in some metastatic IBC patients has responded to the tumor at some stage of cancer development. We showed that IBC tumors from a subset of stage IV patients expressed moderate to high levels of PD-1 (18.2\% of patients) and PD-L1 (36.4\% of patients) on infiltrating immune cells by IHC analysis. In addition, we found a positive correlation between PD-L1 expression and PD-1 expression in our IBC tumor biopsies. Our results are consistent with Bertucci et al., who reported overexpression of PD-L1 mRNA in $38 \%$ of IBC patient tumors that were associated with increased $\mathrm{B}$ and $\mathrm{CD}^{+} \mathrm{T}$ cell gene expression signatures [18]. 
Similarly, two groups recently found that expression of PD-L1 in IBC tumor samples correlated with higher stromal tumor-infiltrating lymphocytes (sTIL) that were highly enriched in $\mathrm{CD}_{2} \mathrm{O}^{+} \mathrm{B}$ cells, and their combined presence was associated with better response to neoadjuvant therapy $[17,22]$. We have expanded upon these results by further showing that expression of PD-1 and PD-L1 in our stage IV IBC samples correlated significantly with infiltration of $\mathrm{CD} 20^{+} \mathrm{B}$ cells and a trending correlation was noted for infiltration of $\mathrm{CD}^{+} \mathrm{T}$ cells. The invasion of the tumor stroma by sTIL is often associated with a better prognosis in ER-negative non-IBC [42]. Although breast cancer is considered moderately immunogenic, the presence of neoantigens seems to elicit an immune response, and infiltrating immune cells play an essential role in the host-defense mechanism against ER-negative non-IBC in both adjuvant and neoadjuvant studies [43, 44]. Van Berckelaer et al. recently showed that PD-L1 expression on sTIL was more frequently observed in IBC than non-IBC except in the $\mathrm{Her}^{+}$subtype [22]. PD-L1 expression on immune cells was seen in $38.6-42.9 \%$ of the IBC patients, and it was significantly higher than in non-IBC patients [22]. Hamm et al. also showed that some IBC tumors had high infiltration of $\mathrm{CD}^{+}$cells expressing PD-L1, and these had genetic profiles predictive of greater incidence of potential neoantigens [21].

As an extension of the previous studies, we also found correlations between PD-L1 expression in the stage IV IBC tumors and immune parameters in peripheral blood. Our results showed that the expression levels of PD-L1 in tumor tissues correlated positively with expression levels of cytolytic granule components (perforin and granzyme B) in peripheral blood $\mathrm{CD} 4^{+} \mathrm{T}$ and $\mathrm{CD} 56^{\mathrm{dim}}$ NK cells. The higher levels of these granule components are indicative of a previously activated state and consistent with the higher levels in immature CD56 ${ }^{\text {bright }}$ NK cells, as compared to healthy controls. Furthermore, we found that higher expression of PD-L1 in the tumors also correlated with a shift from reduced percentages of naïve to increased frequency of effector memory $\mathrm{CD} 8^{+} \mathrm{T}$ cells in peripheral blood. Taken together, these results suggest that the $\mathrm{CD} 4^{+} \mathrm{T}$ and NK cells have been activated and effector memory $\mathrm{CD}^{+} \mathrm{T}$ cells have at some point expanded in response to expression of the immunosuppressive ligand in the tumor in a subset of the metastatic IBC patients. Despite these activation events, these immune cells have declined in overall numbers and presumably progressed to the classical exhausted state after chronic exposure to tumor. $\mathrm{T}$ cell exhaustion is a phenotype defined by poor effector function, such as reduced secretion of IL-2, IFN- $\gamma$, and TNF- $\alpha$ [45]. Reuben and Lee have further found that $\mathrm{CD}^{+} \mathrm{T}$ cells from the blood of patients with non-metastatic IBC had enhanced IFN- $\gamma$ production responses upon $\mathrm{T}$ cell receptor (TCR)-stimulation, while IFN- $\gamma$ production declined again toward levels of healthy donors in patients with metastatic IBC [28]. These results suggest that $\mathrm{CD}^{+} \mathrm{T}$ cell responsiveness may be enhanced in non-metastatic IBC patients. All of these observations imply that immunotherapy should be considered as a potential treatment for those patients exhibiting increased expression of PD-1 and/or PD-L1 in tumor and/or increased numbers of cytolytic effector memory $\mathrm{T}$ cells in peripheral blood. In such patients, blockade of the PD-1/PD-L1 inhibitory axis has the potential to reactivate antigen-experienced, exhausted $\mathrm{T}$ cells toward the tumor and thereby might improve clinical outcome. In fact, four clinical trials are currently testing the efficacy of PD-1 or PDL1 blockade in IBC patients (NCT03515798, NCT02411656, NCT03742986, and NCT03202316).

The data reported in our study support the concept of progressive immune dysfunction as IBC advances to highly metastatic clinical behavior. In fact, IBC is associated with early metastatic dissemination as suggested by higher numbers of circulating tumor cells (CTCs) compared to other forms of breast cancer. It has been shown that IBC patients with higher numbers of CTCs also have a more compromised immune status, which is characterized by reduced percentages of $\mathrm{CD} 4^{+}$helper $\mathrm{T}$ cells, higher percentage of Treg cells, and reduced cytokine-producing $\mathrm{CD}^{+} \mathrm{T}$ cells [29]. Peripheral blood immune cells can contribute to an unfavorable environment for CTC survival, since innate and adaptive immune mechanisms are purportedly responsible for controlling tumor dissemination and, perturbations in the immune surveillance could favor an environment conducive for the survival and dissemination of CTCs, ultimately leading to cancer progression [46]. We can hypothesize that the lower level of immune surveillance in lymphopenic metastatic IBC patients could facilitate additional metastasis, but the ultimate causes of immune dysfunction in IBC need to be better defined. To improve mechanistic understanding, Reddy et al. recently showed greater macrophage infiltration in IBC tumors than in other breast cancers [47], and they further showed that IBC tumors with increased infiltration of mast cells were associated with poorer clinical responses to neoadjuvant chemotherapy [48]. Also, Valeta-Magara et al. recently showed that IBC tumors produce chemokines and cytokines that recruit monocytes and polarize macrophages to the M2 phenotype, which are immunosuppressive and tumor-promoting [49]. Thus, the accumulating evidence suggests that M2 macrophages and the PD-1/PD-L1 axis contribute to the immunosuppressive TME in IBC, although more studies are clearly needed. 


\section{Conclusions}

Through this work, we investigated immune parameters in peripheral blood of metastatic IBC patients by using flow cytometry-based immune phenotyping, which is different from most of the previous studies in IBC that focused on infiltrating immune cells. We further compared these parameters with PD-1 and PD-L1 expression and $\mathrm{T}$ and $\mathrm{B}$ cell infiltration in IBC tumor biopsies by IHC. A limitation of our work is the small cohort of patients that were analyzed. Nonetheless, IBC is a rare cancer in need of more detailed study, and we provide comparison between immune parameters in peripheral blood and within the TME.

Our study provides evidence that the immune system of a subset of patients with stage IV IBC has responded to the tumor. IBC tumor biopsies from most patients expressed clearly detectable levels of PD-1 (18.2\% of patients) and PD-L1 (36.4\% of patients), as defined by staining scores of 3-4 (moderate to high), and expression levels of this checkpoint receptor/ligand pair were correlated in the TME. Interestingly, increased PD-L1 expression in tumor also correlated with higher cytolytic granule components in $\mathrm{NK}$ and $\mathrm{CD}^{+}$helper $\mathrm{T}$ cells from blood, as well as greater frequency of effector memory and lower percentage of naïve $\mathrm{CD} 8^{+}$cytotoxic $\mathrm{T}$ cells in the blood. PD-1 expression in tumor also correlated with increased $\mathrm{CD}_{20}{ }^{+} \mathrm{B}$ cell TIL. These results provide rationale to consider PD-1/PD-L1 blocking immunotherapy as a potential treatment for IBC patients exhibiting increased expression of PD-1 and/or PD-L1 in tumor. In such patients, blockade of the PD-1/PD-L1 inhibitory axis has the potential to reactivate antigenexperienced exhausted $\mathrm{T}$ cells toward the tumor and thereby might improve clinical outcome.

\section{Supplementary Information}

The online version contains supplementary material available at https://doi. org/10.1186/s13058-020-01371-x.

Additional file 1.

\begin{abstract}
Abbreviations
$\mathrm{CD}^{+} \mathrm{T}$ : Cytotoxic T lymphocytes; $\mathrm{CD}^{+} \mathrm{T}$ : Helper T lymphocytes; CTC: Circulating tumor cell; Her2 or ErbB2: Receptor tyrosine-protein kinase erbB-2; ER or ESR1: Estrogen receptor alpha; FDR: False Discovery Rate; FFPE: Formalin-fixed paraffin-embedded; IBC: Inflammatory breast cancer; IHC: Immunohistochemistry; NK: Natural killer; PD-1: Programmed cell death protein 1; PD-L1: Programmed death-ligand 1; PR: Progesterone receptor; OS: Overall survival; PR: Progesterone receptor; sTIL: Stromal tumor-infiltrating lymphocytes; TCR: T cell receptor; TN: Triple-negative breast cancer; Treg: Regulatory T cells; TIL: Tumor-infiltrating lymphocytes; TME: Tumor microenvironment
\end{abstract}

\section{Acknowledgements}

The authors thank Ms. Christina Moon for technical assistance in PD-1/PD-L1 IHC staining, the FCCC Biosample Repository for healthy donor blood samples, the FCCC Pathology Flow Cytometry Laboratory, the FCCC Histopathology Facility, and funding support from FCCC Keystone Program in Blood
Cell Development and Cancer, FCCC Boards of Associates, the Commonwealth of Pennsylvania, and the $\mathrm{NCl}$. We thank Wendy Davis and Michele Pizzo from the FCCC Immunohistochemistry Laboratory of the Department of Pathology for technical assistance in TIL IHC staining. The authors would also like to thank all IBC patients that donated their samples for this research study.

\section{Authors' contributions}

MC and KSC conceived the project and set up logistics to perform the study. RKA coordinated sample collection and distribution. AWM, KSC, and MJ designed and performed the flow cytometry experiments. AJY and AL oversaw the immunohistochemistry analysis and coordinated scoring and image processing. YG coordinated the tumor sample collection to perform TIL staining. KQC coordinated the $\mathrm{HC}$ staining of tumor samples for CD3 and CD20 expression in the FCCC Histopathology Facility. SVF, MFA, KSC, and AWM performed data and statistical analyses and figure preparation, SVF and KSC drafted the manuscript, and all authors contributed to revisions. All authors read and approved the final manuscript.

\section{Funding}

Supported by a grant from Merck Sharp \& Dohme Corp., a subsidiary of Merck \& Co., Inc., Kenilworth, NJ, USA (MSD), the FCCC Keystone Program in Blood Cell Development and Cancer, the FCCC Main Line and Bucks County Boards of Associates, a Health Research Formula Fund grant from the Commonwealth of Pennsylvania (CURE; to K.S.C.), and NCl Comprehensive Cancer Center Support Grant CA06927 (FCCC).

\section{Availability of data and materials}

The data of this work will be made available upon reasonable request.

\section{Ethics approval and consent to participate}

The ethics approvals of this study were granted by the institutional review board (IRB) at Fox Chase Cancer Center (FCCC) as IRB protocols \#99-802 and \#11-866, and all patients and healthy donors provided informed consent in accordance with these protocols.

\section{Consent for publication}

Not applicable.

\section{Competing interests}

This work was partially supported by funds from Merck Sharp \& Dohme Corp., a subsidiary of Merck \& Co., Inc., Kenilworth, NJ, USA (MSD), and JY, LA and CM are employees of MSD. MC has advised Lilly, Cytodyn, Foundation Medicine, G1 Therapeutics, Amarex, and Sermonix and received honoraria from Pfizer and Foundation Medicine. KSC has received research funding from Janssen, Immune Oncology Biosciences, Genentech, BMS, Horizon

Pharma, and NantKwest.

\section{Author details}

${ }^{1}$ Department of Medical Oncology, Fox Chase Cancer Center, Philadelphia, PA 19111, USA. ${ }^{2}$ Blood Cell Development and Function Program, Institute for Cancer Research, Fox Chase Cancer Center, 333 Cottman Ave, Philadelphia, PA 19111, USA. ${ }^{3}$ Present address: Thomas Jefferson University, Sidney Kimmel Medical School, Philadelphia, PA 19107, USA. ${ }^{4}$ Merck \& Co, Inc., Kenilworth, NJ 07033, USA. ${ }^{5}$ Department of Pathology, Fox Chase Cancer Center, Philadelphia, PA 19111, USA. ${ }^{6}$ Histopathology Facility, Fox Chase Cancer Center, Philadelphia, PA 19111, USA. ${ }^{7}$ Protocol Support Laboratory, Institute for Cancer Research, Fox Chase Cancer Center, Philadelphia, PA 19111, USA. ${ }^{8}$ Present address: Northwestern University, Feinberg School of Medicine, Chicago, IL 60611, USA.

Received: 22 May 2020 Accepted: 15 November 2020 Published online: 02 December 2020

\section{References}

1. Anderson WF, Schairer C, Chen BE, Hance KW, Levine PH. Epidemiology of inflammatory breast cancer (IBC). Breast Dis. 2005;22:9-23.

2. Levine PH, Steinhorn SC, Ries LG, Aron JL. Inflammatory breast cancer: the experience of the surveillance, epidemiology, and end results (SEER) program. J Natl Cancer Inst. 1985;74(2):291-7. 
3. Hance KW, Anderson WF, Devesa SS, Young HA, Levine PH. Trends in inflammatory breast carcinoma incidence and survival: the surveillance, epidemiology, and end results program at the National Cancer Institute. J Natl Cancer Inst. 2005;97(13):966-75.

4. Robertson FM, Bondy M, Yang W, Yamauchi H, Wiggins S, Kamrudin S, Krishnamurthy S, Le-Petross H, Bidaut L, Player AN, et al. Inflammatory breast cancer: the disease, the biology, the treatment. CA Cancer J Clin. 2010;60(6):351-75.

5. Wingo PA, Jamison PM, Young JL, Gargiullo P. Population-based statistics for women diagnosed with inflammatory breast cancer (United States). Cancer Causes Control. 2004;15(3):321-8.

6. Fouad TM, Barrera AMG, Reuben JM, Lucci A, Woodward WA, Stauder MC, Lim B, DeSnyder SM, Arun B, Gildy B, et al. Inflammatory breast cancer: a proposed conceptual shift in the UICC-AJCC TNM staging system. Lancet Oncol. 2017;18(4):e228-32.

7. Fouad TM, Kogawa T, Liu DD, Shen Y, Masuda H, El-Zein R, Woodward WA, Chavez-MacGregor M, Alvarez RH, Arun B, et al. Overall survival differences between patients with inflammatory and noninflammatory breast cancer presenting with distant metastasis at diagnosis. Breast Cancer Res Treat. 2015;152(2):407-16.

8. Dawood S, Merajver SD, Viens P, Vermeulen PB, Swain SM, Buchholz TA, Dirix LY, Levine PH, Lucci A, Krishnamurthy S, et al. International expert panel on inflammatory breast cancer: consensus statement for standardized diagnosis and treatment. Ann Oncol. 2011;22(3):515-23.

9. Woodward WA, Cristofanilli M. Inflammatory breast cancer. Semin Radiat Oncol. 2009;19(4):256-65.

10. Rowan K. Inflammatory breast cancer: new hopes and many hurdles. J Natl Cancer Inst. 2009;101(19):1302-4.

11. Ueno NT, Espinosa Fernandez JR, Cristofanilli M, Overmoyer B, Rea D, Berdichevski F, El-Shinawi M, Bellon J, Le-Petross HT, Lucci A, et al. International Consensus on the Clinical Management of Inflammatory Breast Cancer from the Morgan Welch Inflammatory Breast Cancer Research Program 10th Anniversary Conference. J Cancer. 2018;9(8):1437-47.

12. Moslehi R, Freedman E, Zeinomar N, Veneroso C, Levine PH. Importance of hereditary and selected environmental risk factors in the etiology of inflammatory breast cancer: a case-comparison study. BMC Cancer. 2016;16: 334.

13. Bertucci F, Finetti $P$, Birnbaum D, Viens $P$. Gene expression profiling of inflammatory breast cancer. Cancer. 2010;116(11 Suppl):2783-93.

14. Cakar B, Surmeli Z, Oner PG, Yelim ES, Karabulut B, Uslu R. The impact of subtype distribution in inflammatory breast cancer outcome. Eur J Breast Health. 2018;14(4):211-7.

15. Vikas $P$, Borcherding $N$, Zhang $W$. The clinical promise of immunotherapy in triple-negative breast cancer. Cancer Manag Res. 2018;10:6823-33.

16. Francisco LM, Sage PT, Sharpe AH. The PD-1 pathway in tolerance and autoimmunity. Immunol Rev. 2010;236:219-42.

17. Arias-Pulido H, Cimino-Mathews A, Chaher N, Qualls C, Joste N, Colpaert C, Marotti JD, Foisey M, Prossnitz ER, Emens LA, et al. The combined presence of CD20 + B cells and PD-L1 + tumor-infiltrating lymphocytes in inflammatory breast cancer is prognostic of improved patient outcome. Breast Cancer Res Treat. 2018;171(2):273-82.

18. Bertucci F, Finetti $P$, Colpaert C, Mamessier E, Parizel M, Dirix L, Viens $P$, Birnbaum D, van Laere S. PDL1 expression in inflammatory breast cancer is frequent and predicts for the pathological response to chemotherapy. Oncotarget. 2015;6(15):13506-19.

19. Bertucci F, Rypens C, Finetti P, Guille A, Adelaide J, Monneur A, Carbuccia N, Garnier S, Dirix P, Goncalves A, et al. NOTCH and DNA repair pathways are more frequently targeted by genomic alterations in inflammatory than in non-inflammatory breast cancers. Mol Oncol. 2020;14(3):504-19.

20. Bertucci F, Ueno NT, Finetti $P$, Vermeulen $P$, Lucci A, Robertson FM, Marsan M, Iwamoto T, Krishnamurthy $S$, Masuda $H$, et al. Gene expression profiles of inflammatory breast cancer: correlation with response to neoadjuvant chemotherapy and metastasis-free survival. Ann Oncol. 2014;25(2):358-65.

21. Hamm CA, Moran D, Rao K, Trusk PB, Pry K, Sausen M, Jones S, Velculescu VE, Cristofanilli M, Bacus S. Genomic and immunological tumor profiling identifies targetable pathways and extensive CD8+/PDL1+ immune infiltration in inflammatory breast cancer tumors. Mol Cancer Ther. 2016; 15(7):1746-56

22. Van Berckelaer C, Rypens C, van Dam P, Pouillon L, Parizel M, Schats KA, Kockx M, Tjalma WAA, Vermeulen $P$, van Laere $S$, et al. Infiltrating stromal immune cells in inflammatory breast cancer are associated with an improved outcome and increased PD-L1 expression. Breast Cancer Res. 2019;21(1):28.

23. MacFarlane AW 4th, Jillab M, Smith MR, Alpaugh RK, Cole ME, Litwin S, Millenson MM, Al-Saleem T, Cohen AD, Campbell KS. NK cell dysfunction in chronic lymphocytic leukemia is associated with loss of the mature cells expressing inhibitory killer cell Ig-like receptors. Oncoimmunology. 2017;6(7): e1330235.

24. MacFarlane AW 4th, Jillab M, Plimack ER, Hudes GR, Uzzo RG, Litwin S, Dulaimi E, Al-Saleem T, Campbell KS. PD-1 expression on peripheral blood cells increases with stage in renal cell carcinoma patients and is rapidly reduced after surgical tumor resection. Cancer Immunol Res. 2014;2:320-31.

25. Yearley JH, Gibson C, Yu N, Moon C, Murphy E, Juco J, Lunceford J, Cheng J, Chow LQM, Seiwert TY, et al. PD-L2 expression in human tumors: relevance to anti-PD-1 therapy in cancer. Clin Cancer Res. 2017;23(12):3158-67.

26. Benjamini $Y$, Hochberg $Y$. Controlling the false discovery rate - a practical and powerful approach to multiple testing. J R Stat Soc B. 1995;57(1):289300.

27. Campbell KS, Hasegawa J. Natural killer cell biology: an update and future directions. J Allergy Clin Immunol. 2013;132(3):536-44.

28. Reuben JM, Bang-Ning L. Immunology of inflammatory breast cancer (Chapter 17). In: Inflammatory Breast Cancer: An Update (NT Ueno and M Cristofanilli eds); 2012.

29. Mego M, Gao H, Cohen EN, Anfossi S, Giordano A, Sanda T, Fouad TM, De Giorgi U, Giuliano M, Woodward WA, et al. Circulating tumor cells (CTC) are associated with defects in adaptive immunity in patients with inflammatory breast cancer. J Cancer. 2016;7(9):1095-104.

30. Mosmann TR, Li L, Sad S. Functions of CD8 T-cell subsets secreting different cytokine patterns. Semin Immunol. 1997;9(2):87-92.

31. Boyman O, Letourneau S, Krieg C, Sprent J. Homeostatic proliferation and survival of naive and memory T cells. Eur J Immunol. 2009;39(8):2088-94.

32. Menetrier-Caux C, Ray-Coquard I, Blay JY, Caux C. Lymphopenia in cancer patients and its effects on response to immunotherapy: an opportunity for combination with cytokines? J Immunother Cancer. 2019;7(1):85.

33. Saroha S, Uzzo RG, Plimack ER, Ruth K, Al-Saleem T. Lymphopenia is an independent predictor of inferior outcome in clear cell renal carcinoma. J Urol. 2013;189(2):454-61.

34. Trinchieri G. Biology of natural killer cells. Adv Immunol. 1989;47:187-376.

35. Caligiuri MA. Human natural killer cells. Blood. 2008:112(3):461-9.

36. Ljunggren HG, Karre K. In search of the 'missing self': MHC molecules and NK cell recognition. Immunol Today. 1990;11(7):237-44.

37. MacFarlane AW 4th, Campbell KS. Signal transduction in natural killer cells. Curr Top Microbiol Immunol. 2006;298:23-57.

38. Mamessier E, Sylvain A, Bertucci F, Castellano R, Finetti P, Houvenaeghel G, Charaffe-Jaufret E, Birnbaum D, Moretta A, Olive D. Human breast tumor cells induce self-tolerance mechanisms to avoid NKG2D-mediated and DNAM-mediated NK cell recognition. Cancer Res. 2011;71(21):6621-32.

39. Krzewski K, Coligan JE. Human NK cell lytic granules and regulation of their exocytosis. Front Immunol. 2012;3:335.

40. Mamessier E, Pradel LC, Thibult ML, Drevet C, Zouine A, Jacquemier J, Houvenaeghel G, Bertucci F, Birnbaum D, Olive D. Peripheral blood NK cells from breast cancer patients are tumor-induced composite subsets. J Immunol. 2013;190(5):2424-36.

41. Mamessier E, Sylvain A, Thibult ML, Houvenaeghel G, Jacquemier J, Castellano R, Goncalves A, Andre P, Romagne F, Thibault G, et al. Human breast cancer cells enhance self tolerance by promoting evasion from NK cell antitumor immunity. J Clin Invest. 2011;121(9):3609-22.

42. Ahn SG, Jeong J, Hong S, Jung WH. Current issues and clinical evidence in tumor-infiltrating lymphocytes in breast cancer. J Pathol Transl Med. 2015; 49(5):355-63.

43. Denkert C, von Minckwitz G, Darb-Esfahani S, Lederer B, Heppner BI, Weber KE, Budczies J, Huober J, Klauschen F, Furlanetto J, et al. Tumour-infiltrating lymphocytes and prognosis in different subtypes of breast cancer: a pooled analysis of 3771 patients treated with neoadjuvant therapy. Lancet Oncol. 2018;19(1):40-50.

44. Loi S, Sirtaine N, Piette F, Salgado R, Viale G, Van Eenoo F, Rouas G, Francis $P$, Crown JP, Hitre $E$, et al. Prognostic and predictive value of tumorinfiltrating lymphocytes in a phase III randomized adjuvant breast cancer trial in node-positive breast cancer comparing the addition of docetaxel to doxorubicin with doxorubicin-based chemotherapy: BIG 02-98. J Clin Oncol. 2013;31(7):860-7.

45. Wherry EJ. T cell exhaustion. Nat Immunol. 2011;12(6):492-9. 
46. Hanahan D, Weinberg RA. Hallmarks of cancer: the next generation. Cell. 2011;144(5):646-74.

47. Reddy JP, Atkinson RL, Larson R, Burks JK, Smith D, Debeb BG, Ruffell B, Creighton CJ, Bambhroliya A, Reuben JM, et al. Mammary stem cell and macrophage markers are enriched in normal tissue adjacent to inflammatory breast cancer. Breast Cancer Res Treat. 2018;171(2):283-93.

48. Reddy SM, Reuben A, Barua S, Jiang H, Zhang S, Wang L, Gopalakrishnan V, Hudgens CW, Tetzlaff MT, Reuben JM, et al. Poor response to neoadjuvant chemotherapy correlates with mast cell infiltration in inflammatory breast cancer. Cancer Immunol Res. 2019;7(6):1025-35.

49. Valeta-Magara A, Gadi A, Volta V, Walters B, Arju R, Giashuddin S, Zhong H, Schneider RJ. Inflammatory breast cancer promotes development of M2 tumor-associated macrophages and cancer mesenchymal cells through a complex chemokine network. Cancer Res. 2019;79(13):3360-71.

\section{Publisher's Note}

Springer Nature remains neutral with regard to jurisdictional claims in published maps and institutional affiliations.

Ready to submit your research? Choose BMC and benefit from:

- fast, convenient online submission

- thorough peer review by experienced researchers in your field

- rapid publication on acceptance

- support for research data, including large and complex data types

- gold Open Access which fosters wider collaboration and increased citations

- maximum visibility for your research: over $100 \mathrm{M}$ website views per year

At $\mathrm{BMC}$, research is always in progress.

Learn more biomedcentral.com/submissions 